\title{
Metal-azasterol complexes: Synthesis, characterization, interaction studies with DNA and TrxR and Biological Evaluation
}

\author{
Gonzalo Visbal, ${ }^{1,2}$ Angel Rubén Higuera-Padilla, ${ }^{3}$ Luana Pereira Borba-Santos, ${ }^{4}$ Wanderley de Souza, ${ }^{5}$ \\ Sonia Rozental ${ }^{4}$ and Maribel Navarro*1,6
}

1 Diretoria de Metrologia Aplicada às Ciências da Vida, Instituto Nacional de Metrologia, Qualidade e Tecnologia (INMETRO), Rio de Janeiro, Brazil.

2 Centro de Desenvolvimento em Saúde (CDTS). Fundação Oswaldo Cruz - Fiocruz. Rio de Janeiro, RJ, Brazil.

3 Laboratório de Química Bioinorgánica. Instituto Venezolano de Investigaciones Científicas (IVIC), Miranda, Venezuela.

${ }^{4}$ Laboratório de Biologia Celular de Fungos, Instituto de Biofísica Carlos Chagas Filho, Universidade Federal do Rio de Janeiro, Rio de Janeiro, RJ, Brazil.

5 Laboratório de Ultraestrutura Celular Hertha Meyer, Instituto de Biofísica Carlos Chagas Filho, Universidade Federal do Rio de Janeiro, Rio de Janeiro, RJ, Brazil.

6 Departamento de Química - Instituto de Ciências Exatas, Universidade Federal de Juiz de Fora (UFJF). Minas Gerais, MG, Brazil.

* Corresponding authors Email: gvisbal@gmail.com, maribel.navarro@ufjf.edu.br, maribelnava@gmail.com

Received October 18 $8^{\text {th }}, 2016$; Accepted March $8^{\text {th }}, 2017$.

\begin{abstract}
A new azasterol 22-hydrazine-imidazolin-2-yl-chol-5-ene$3 \beta$-ol (AH3) and their derivatives $[\mathrm{Au}(\mathbf{A H} \mathbf{3}) \mathrm{Cl}]$ (1) and $\left[\mathrm{Cu}(\mathbf{A H 3})_{2}\left(\mathrm{H}_{2} \mathrm{O}\right)_{2}\right]\left(\mathrm{NO}_{3}\right)_{2}(2)$ were synthesized and characterized by a combination of elemental analyses, ${ }^{1} \mathrm{H}$ and ${ }^{13} \mathrm{C}$-NMR, UV-vis and infrared spectroscopies. The interactions with two targets DNA and TrxR were investigated. The results from these studies suggested that these metal-azasterol complexes interact with DNA most probably by covalent binding. Complex 1 showed also the ability to strongly inhibit TrxR. Additionally, their activities against yeast cells of Sporothrix $s p p$. were evaluated; finding that complex 1 was the most active, even better than itraconazole.
\end{abstract}

Keywords: Azasterol; gold; copper; DNA; thiorredoxin reductase; Sporothrix spp.

\section{Introduction}

Several research areas have looked for the identification of new drug targets. In the case of anti-fungi agents at least four major areas can be mentioned: i) Cell wall architecture, ii) Signaling pathways, iii) Cellular machinery, and iv) Plasma membrane composition [1]. Within this context, one of our research efforts has been focused on the plasma membrane composition, because several studies have demonstrated the potent effects of different ergosterol biosynthesis inhibitors (EBIs) on various pathogenic microorganisms, such as parasites and fungus, due to the fact that these agents interfere with some essential steps in the ergosterol biosynthesis pathway. Particular attention was given to inhibitors of $\Delta^{24}$-sterol methyltransferase (24-SMT, an enzyme of ergosterol biosynthesis restricted to plants, protozoa, and fungi) that showed antimicrobial effects against Trypanosoma cruzi, Leishmania donovani, Leishmania amazonensis, Leishmania mexicana, Pneumocystis carinii (now P. jirovecii),
Resumen. Un nuevo azasterol 22-hidrazina-imidazolin-2-il-col-5-en$3 \beta$-ol (AH3) y sus derivados $[\mathrm{Au}(\mathbf{A H 3}) \mathrm{Cl}](\mathbf{1})$ y $\left[\mathrm{Cu}(\mathbf{A H 3})_{2}\left(\mathrm{H}_{2} \mathrm{O}\right)_{2}\right]$ $\left(\mathrm{NO}_{3}\right)_{2}(2)$ fueron sintetizados y caracterizados por técnicas espectroscopias como $\mathrm{RMN}{ }^{1} \mathrm{H},{ }^{13} \mathrm{C}$, UV-vis, infrarrojo y análisis elemental. Se investigaron las interacciones de estos compuestos sobre dos blancos moleculares el ADN y la TrxR. Los resultados encontrados sugirieren que estos complejos metal-azasterol interactúan con el ADN covalentemente. El complejo 1 también mostró tener la capacidad de inhibir fuertemente la TrxR. Además, fueron evaluadas sus actividades contra Sporothrix spp., encontrando que complejo 1 fue el más activo, incluso mejor que el itraconazol.

Palabras clave: Azasterol; Oro; Cobre; Tiorreduxina reductasa; Sporothrix spp.

Paracoccidioides brasiliensis, Candida spp, and Cryptococcus neoformans, $[2,3,4,5,6,7,8,9,10,11]$. A new 24-SMT inhibitor belonging to the sterol hydrazone class, named 22-hydrazoneimidazolin-2-yl-chol-5-ene-3 $\beta$-ol (H3) showed a significant anti-proliferative activity against the dimorphic fungus Paracoccidioides brasiliensis [9,12], and Cryptococcus neoformans [11]. More recently, its effects on the growth of Sporothrix schenckii and Sporothrix brasiliensis was described, and compared to that of itraconazole [13]. GC-MS analysis of cell sterol composition showed that sterols present in control cells (ergosterol and precursors) were replaced mainly by lanosterol after $\mathrm{H} 3$ exposure. In contrast, itraconazole only partially inhibited ergosterol biosynthesis, and promoted accumulation of nine $14 \alpha-$ methyl sterols. Thus, inhibition of the enzyme 24-SMT showed a strong antiproliferative effect via disruption of ergosterol homeostasis, suggesting that this enzyme is a promising target for novel antifungal therapies against sporotrichosis. 
Besides targeting the ergosterol in the membrane, our current interests are also focusing on the development of alternative chemotherapies against fungal and parasitic infection, based on the coordination of ergosterol biosynthesis inhibitors to metal-containing fragments, with the aim of enhancing their activity and diminishing their toxicity to human cells $[14,15,16,17]$. In fact, a variety of metal complexes based on this strategy have been already developed as anti-Chagas diseases $[18,19]$ and leishmanicidal agents $[18,19,20]$.

Recently, we reported the synthesis of platinum-sterol hydrazone complexes and their activities as anti-trypanosomatid [21]. The 24-SMT inhibitors used as ligands were 20-hydrazone-imidazoline-2-yl-5 $\alpha$-pregnan-3 $\beta$-ol (H1) and 22-hydrazoneimidazoline-2-yl-chol-5-ene-3 $\beta$-ol (H3 mentioned above). The results showed potent anti-trypanosomatid activity of the sterol hydrazone analogues and their platinum complexes. Likewise, $\mathrm{H} 3$ and trans- $\left[\mathrm{Pt}(\mathrm{H} 3)_{2}(\mathrm{Cl})_{2}\right]$ showed low cytotoxicity against human immunocompetent cells.

Encouraged by these findings, in current work we performed the synthesis and characterization of a new analogue of H3, the 22-hydrazine-imidazolin-2-yl-chol-5-en-3 $\beta$-ol (sterol hydrazine class) (AH3, Fig. 1) and its two novel gold and copper derivatives (Fig. 2). Furthermore, we explored their possible interactions on two known important metallodrug targets such as DNA $[22,23,24]$ and thioredoxin reductase (TrxR), particularly important for gold complexes $[25,26,27,28,29]$. In addition, their biological effects were evaluated on Sporothrix species, which is a fungal subcutaneous mycosis widespread in several countries, including Brazil [30]. The search for new and more effective antifungal drugs to treat sporotrichosis is becoming a priority, since no vaccine is currently available [31] and its current treatment is restricted to itraconazole [32], which has severe side effects, high costs and can result in the emergence of unresponsive clinical cases [33,34].

\section{Results and Discussion}

\section{Synthesis and characterization}

The azasterol AH3 (See Fig. 1) was synthesized starting with 3ß-hydroxy-23,24-bisnor-5-cholenic acid I, which was protected as a tetrahydropyranyl ether (THP) in THF as solvent and catalytic amounts of p-TsOH to obtain the intermediate II (Fig. 1). Without prior purification, reduction of the carboxylic acid group with lithium aluminium hydride $\left(\mathrm{LiAlH}_{4}\right)$ produced a primary alcohol III in $89 \%$ yield. Characterization of compound III has been determined previously [9]; nevertheless, it is important to note that the formation of methylene group in the side chain of the sterol will be important for the signal assignment of the side chain of the metal complexes. The new methylene group (H-22) appears as signals split into two multiple at $3.63 \mathrm{ppm}$ and $3.34 \mathrm{ppm}$, indicating that they are not magnetically equivalent. Other two signals as multiples at $3.89 \mathrm{ppm}$ and $3.51 \mathrm{ppm}$ are due to H-5' equatorial of the THP group, and $\mathrm{H}-3$ / H-5'axial of the THP group respectively. The ${ }^{13} \mathrm{C}-\mathrm{NMR}$ chemical shift of carbons C-3, C-22 and C-5'(THP) were 75.9, 68.0 and $62.7 \mathrm{ppm}$ respectively. Conversion of the alcohol to the corresponding halide (bromide) was carried out using $\mathrm{N}, \mathrm{N}, \mathrm{N}^{\prime}, \mathrm{N}^{\prime}$-tetramethylethylendiamine, carbon tetrabromide and triphenylphosphine (Appel reaction) to obtain the intermediate IV with $96 \%$ yield. Deprotection of IV with $\mathrm{HCl}$ in refluxing ethanol, resulted in $\mathbf{V}$ in $98 \%$ yield. The ${ }^{1} \mathrm{H}$-NMR shift data of the side chain allow unambiguous differentiation of the methylene protons (H-22). One of them had high field shifts from $3.63 \mathrm{ppm}$ to $3.49 \mathrm{ppm}$, overlapping with $\mathrm{H}-3$, while, the other proton remains in the same position at $3.32 \mathrm{ppm}$. In the ${ }^{13} \mathrm{C}$-NMR spectrum of $\mathbf{V}, \mathbf{C}-22$ appears at $43.7 \mathrm{ppm}$ indicating that bromine substitution effect shifts this carbon resonance to high-field.

Finally, the compound $\mathbf{V}$ was treated with 2-hydrazino-2-imidazoline hydrobromide and DBU in refluxing acetonitrile to afford the new 22-hydrazino-imidazolin-2-yl-chol-5-en-3 $\beta$-ol (AH3) in $72 \%$ yield. The elemental analysis of the $\mathbf{A H 3}$ was found in good agreement with the calculated data. The infrared spectra of AH3 showed a sharp band at $1640 \mathrm{~cm}^{-1}$ corresponding to the stretching $\mathrm{C}=\mathrm{N}$ of the hydrazino group. Likewise, the same spectrum showed broad band in the region 3000-3800 $\mathrm{cm}^{-1}$ associated to the stretching $\mathrm{NH}$ and $\mathrm{OH}$ at $3417 \mathrm{~cm}^{-1}$. The ${ }^{1} \mathrm{H}-\mathrm{NMR}$ spectrum of $\mathbf{A H} \mathbf{3}$ in DMSO- $\mathrm{d}_{6}$ showed on the lowfield two signals singlet, one at $5.24 \mathrm{ppm}$ due to H-6 olefin proton, another at $5.04 \mathrm{ppm}$ due to one of the $\mathrm{NH}$ hydrazino group. H-22, H-24, H-25 and H-3 appeared as a broad complex signal in the range of 3.6 to $3.0 \mathrm{ppm}$. At high-field the spectrum showed a doublet at $1.01 \mathrm{ppm}$, and two singlets at 0.93 and 0.65 ppm assigned to the characteristic methyl groups, H-21, H-19 and $\mathrm{H}-18$ respectively.

In the ${ }^{13} \mathrm{C}-\mathrm{NMR}$ spectrum of $\mathbf{A H 3}, \mathrm{C}-23(-\mathrm{C}=\mathrm{N})$ of the imidazoline group appeared at $163.7 \mathrm{ppm}$, whereas, the carbons C-5 and C- 6 of the sterol nucleus structure were observed at 141.28 and $120.3 \mathrm{ppm}$ respectively. In addition, with the aid of COSY and HMQC data the side-chain of the AH3 was unambiguously assigned, C-22 was observed at $57.5 \mathrm{ppm}$, indicating that nitrogen substitution effect shifts the carbon resonance to low-field. Likewise, C-24 and C-25 were assigned at $49.5 \mathrm{ppm}$. All structures described above were determined by comprehensive analyses of their elemental analyses, mass spectrometry, ${ }^{1} \mathrm{H}$ and ${ }^{13} \mathrm{C}$ NMR, COSY, HMQC, and IR spectroscopy data. The data are given in the experimental section.

In the same way, two new metal-AH3 complexes $[\mathrm{Au}(\mathbf{A H 3}) \mathrm{Cl}](\mathbf{1})$ and $\left[\mathrm{Cu}(\mathbf{A H 3})_{2}\left(\mathrm{H}_{2} \mathrm{O}\right)_{2}\right]\left(\mathrm{NO}_{3}\right)_{2}$ (2) were synthesized by reaction of $\mathbf{A H 3}$ with the appropriate metallic source under mild conditions, as summarized in the Fig. 2. Gold-azasterol complex (1) was synthesized at room temperature by the reaction between $\mathrm{AuCl}(\mathrm{THT})$ and the ligand $\mathbf{A H 3}$ in dichloromethane for 96 hours. While, copper-AH3 complex (2) was prepared by the reaction between $\mathrm{Cu}\left(\mathrm{NO}_{3}\right)_{2} \cdot 3 \mathrm{H}_{2} \mathrm{O}$ and AH3 in methanol, under reflux for 2 hours. Both metal compounds were air-stable. Their elemental analyses were in agreement with the molecular formula proposed for these metal complexes (see experimental section). 

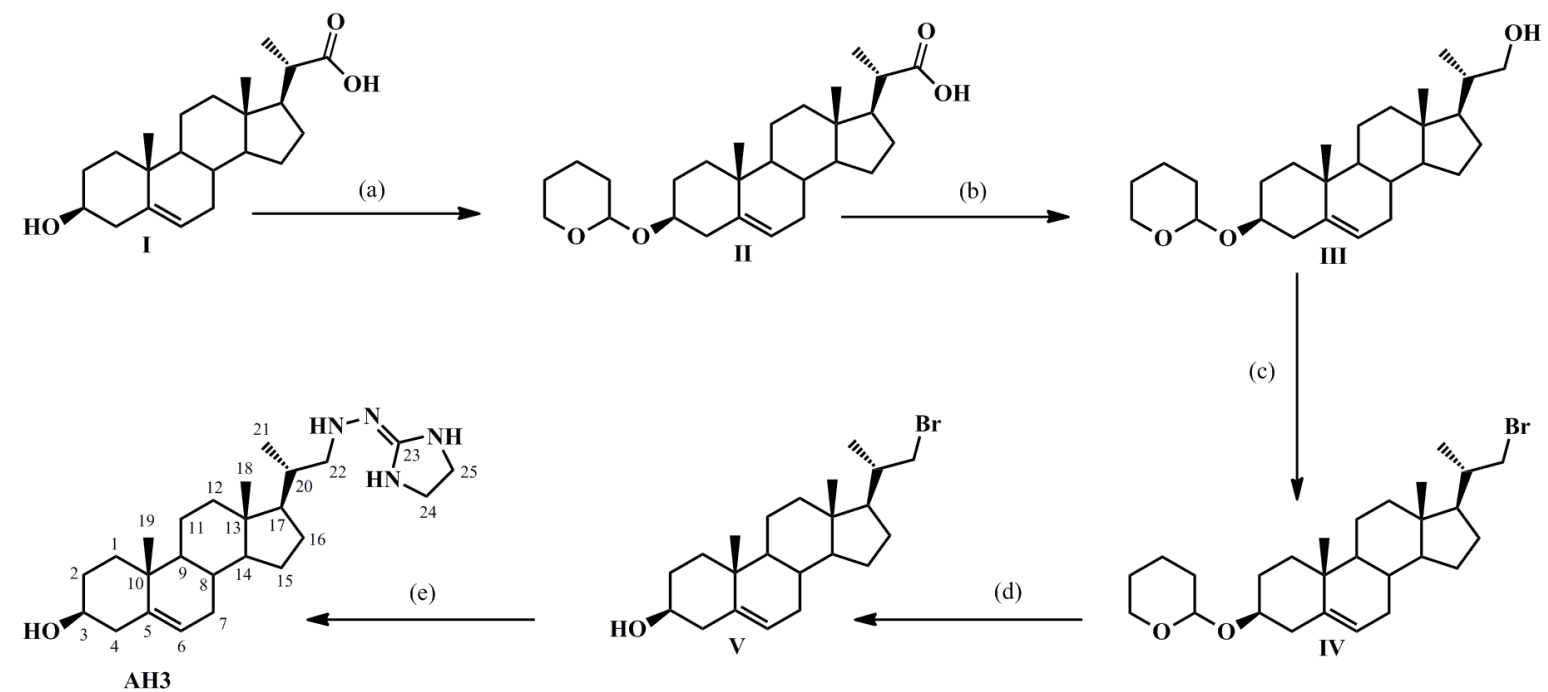

Fig. 1. Synthesis of AH3, a) THF, DHP, PTSA, rt (room temperature); b) THF, LiAlH4, $0{ }^{\circ} \mathrm{C}$ to rt; c) $\mathrm{CH}_{2} \mathrm{Cl}_{2}, \mathrm{TMEDA}^{\mathrm{CBBr}} \mathrm{CPh}_{3}, \mathrm{rt}$; d) $\mathrm{EtOH}$, $\mathrm{HCl}$, rt; e) $\mathrm{CH}_{3} \mathrm{CN}, \mathrm{C}_{3} \mathrm{H}_{8} \mathrm{~N}_{4} \cdot \mathrm{HBr}, \mathrm{DBU}$, reflux.

The IR spectra of these metal complexes showed frequencies distinctly associated with the main and characteristic functional group of the $\mathbf{A H 3}$, interestingly the band corresponding to stretching associated to $\mathrm{NH}$ and $\mathrm{OH}$ at $3417 \mathrm{~cm}^{-1}$ was clearly shifted to $3444 \mathrm{~cm}^{-1}$ for both complex $\mathbf{1}$ and $\mathbf{2}$. The band corresponding to the stretching $\mathrm{C}=\mathrm{N}$ was shifted $6 \mathrm{~cm}^{-1}$ to lower frequency for both complex $\mathbf{1}$ and $\mathbf{2}$. In addition, for complex $\mathbf{2}$ was also possible to observe a sharp band at $1384 \mathrm{~cm}^{-1}$ corresponding to the stretching vibrations of the nitrate $\left(\mathrm{NO}_{3}\right)$ group, which is characteristic for ionic nitrates complexes [35]. No bands in the region for coordinated nitrate were observed. The optical absorption spectra of the new metal complexes are essentially analogous to the free ligand, and they were characterized by intense absorption bands in the UV region characteristic of $n \rightarrow \pi^{*}$ transitions of the imine group.

NMR signals could be assigned on the basis of $1 \mathrm{D}\left({ }^{1} \mathrm{H}\right.$ and $\left.{ }^{13} \mathrm{C} \mathrm{NMR}\right)$ and $2 \mathrm{D}$ (COSY and HMQC) data. It is worth pointing out, that NMR experiments were performed using DMSO- $\mathrm{d}_{6}$. The ${ }^{1} \mathrm{H}$ and ${ }^{13} \mathrm{C}$ NMR chemical shift variation of each signal with respect to those of the free ligand $(\Delta \delta)$ were used as a parameter to deduce the mode of bonding of $\mathbf{A H 3}$ to the metal. ${ }^{1} \mathrm{H}-\mathrm{NMR}$ spectrum of complex $\mathbf{1}$ showed the presence of two singlets around of 0.65 and $0.93 \mathrm{ppm}$, corresponding to the H-18 and H-19 protons respectively. A signal doublet around $1.03 \mathrm{ppm}$ belongs to the $\mathrm{H}-21$. It was also observed a broad signal between $3.56 \mathrm{ppm}$ and $3.0 \mathrm{ppm}$ which was assigned to the methylene groups $(\mathrm{H}-22, \mathrm{H}-24$ and $\mathrm{H}-25)$ of the imidazoline and H3. Likewise, the olefin proton $\mathrm{H} 6$ and the singlet signal of $\mathrm{NH}$ group remain on their chemical shift at $5.24 \mathrm{ppm}$ and $5.04 \mathrm{ppm}$ respectively; in general all signals corresponding to AH3 were displayed in the ${ }^{1} \mathrm{H}-\mathrm{NMR}$ spectrum of the complex 1, indicating that this ligand was coordinated to gold. However, the peak corresponding to protons $\mathrm{H}-22$ (which are the protons expected to shift, due to the coordination to $\mathrm{Au}$ atom) is overlapped with other protons (above mentioned) and the water protons of DMSO- $\mathrm{d}_{6}$, making it difficult to calculate the chemical shift variation with respect to those of the free AH3. Interestingly, in the ${ }^{1} \mathrm{H}-\mathrm{NMR}$ spectrum of complex $\mathbf{2}$ it was possible to assign some chemical shifts, although, it is a paramagnetic complex.

On the other hand, all signals in the ${ }^{13} \mathrm{C}-\mathrm{NMR}$ spectrum for complex 1 were assigned, selected data ${ }^{13} \mathrm{C}$-NMR are given in Table1. It was noticeable that the peaks of C-22, C-23, C-24 and C-25 were clearly shifted 8.0,2.2 and 7.3 ppm upfield with respect to those of the free ligand, the rest of the signals showed no significant shifts. Similar behaviour was observed for complex 2 (see Table 1). These effects suggest that AH3 is coordinated to both gold and copper through the nitrogen atom of the $\mathrm{C}=\mathrm{N}$ exocyclic of the imidazol ring, a good donor site in this molecule (Fig. 2).

According to the available data, the formulation proposed for the new gold-azasterol compound $\mathbf{1}$ corresponds to 14-electron $\mathrm{Au}(\mathrm{I})$ complex in a lineal coordination geometry, while the structure of complex 2 corresponds to 17 -electrons $\mathrm{Cu}(\mathrm{II})$ in a tetragonal coordination geometry (Fig. 2).[36]

\section{DNA interaction studies}

The ability of metal-AH3 complexes to interact with DNA, an important bio-target, was examined using several physical chemical techniques that can supply information and give clear vision with respect to the interaction that is taking place between them $[37,38,39]$. For this, we performed UV-visible absorption titration in order to determine the equilibrium binding constant $\left(\mathrm{K}_{\mathrm{b}}\right)$ of the $\mathbf{A H} \mathbf{3}$ and its metal derivatives $\mathbf{1}$ and $\mathbf{2}$ with ct-DNA, monitoring the perturbation of the absorption electronic spectrum of each compound after the addition of ct-DNA 
Table 1. Selected ${ }^{13} \mathrm{C}$-NMR Data for metal-azasterol complexes

\begin{tabular}{|c|c|c|c|c|c|}
\hline \multirow{2}{*}{$\frac{\text { Comp. }}{\text { Asig. }}$} & \multirow{2}{*}{$\begin{array}{c}\mathbf{A H 3} \\
(\mathrm{ppm})\end{array}$} & \multicolumn{2}{|c|}{$\begin{array}{c}{[\mathrm{Au}(\mathbf{A H 3}) \mathrm{Cl}](\mathbf{1})} \\
(\mathrm{ppm})\end{array}$} & \multicolumn{2}{|c|}{$\begin{array}{c}{\left[\mathrm{Cu}(\mathbf{A H 3})_{2}\left(\mathrm{H}_{2} \mathrm{O}\right)_{2}\right]\left(\mathrm{NO}_{3}\right)_{2}(\mathbf{2})} \\
(\mathrm{ppm})\end{array}$} \\
\hline & & $\delta$ & $\Delta \delta$ & $\delta$ & $\Delta \delta$ \\
\hline $\mathrm{C} 22$ & 57.5 & 49.5 & 8.0 & 55.5 & 2.0 \\
\hline $\mathrm{C} 24, \mathrm{C} 25$ & 49.6 & 42.3 & 7.3 & 42.2 & 7,4 \\
\hline
\end{tabular}

ND: no detected.

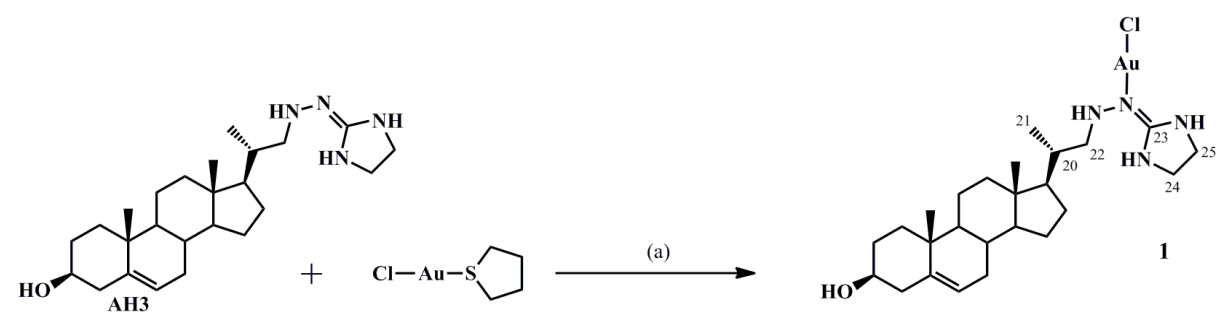

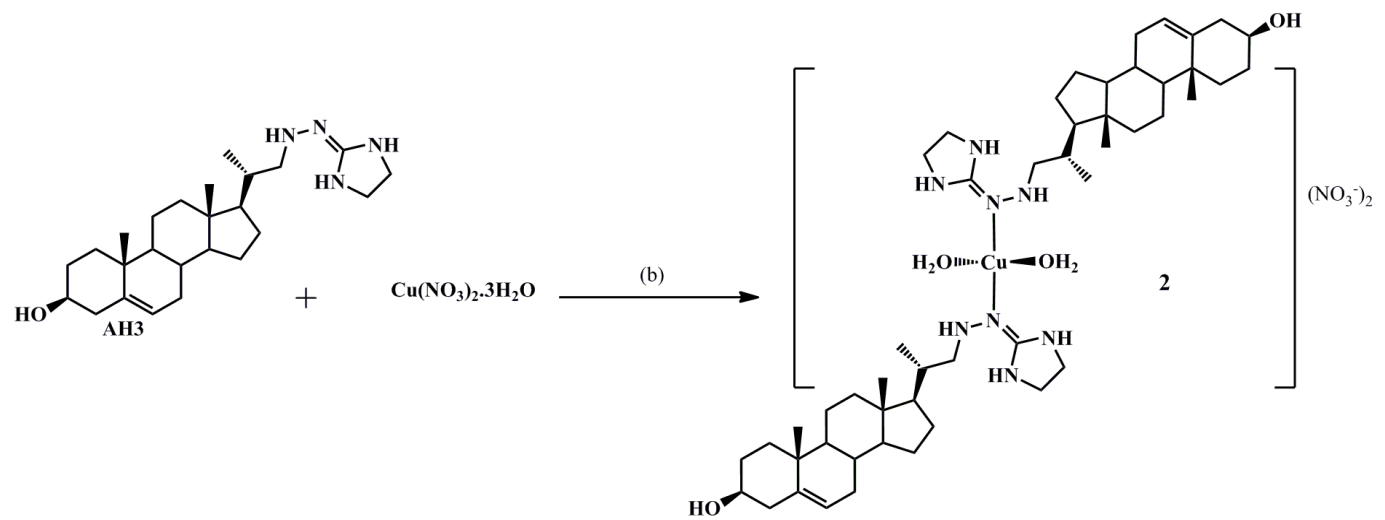

Fig. 2. Synthesis of the new azasterol-metal complexes 1 and 2. (a) $\mathrm{CH}_{2} \mathrm{Cl}_{2}, \mathrm{rt}$, 96h; (b) $\mathrm{MeOH}, \Delta, 2 \mathrm{~h}$.

and using the equation described in the Experimental Section. The hypochromism, bathochromic shift and corresponding binding constants $\left(\mathrm{K}_{\mathrm{b}}\right)$ for all compounds are presented in Table 2. It is worth mentioning that the absorption spectra of $\mathbf{A H 3}$ and complex 2 with increasing concentrations of ct-DNA showed similar behaviour (Fig. 3). A significant decrease in their absorption intensity was observed for both compounds, showing hypochromism around 50\% and 39\% respectively. The $\mathrm{K}_{\mathrm{b}}$ values obtained for $\mathbf{A H 3}$ and complex $\mathbf{2}$ are within the interval for compounds which have moderate binding affinity with the DNA [40, 41], whilst complex 1 exhibited slight hypochromism (about 5\% ) upon addition of ct-DNA.

In order to collect further information on the interaction of these compounds with the DNA, we determined the melting temperature $\left(\mathrm{T}_{\mathrm{m}}\right)$ from the thermal denaturation curves of DNA (Figure 4) obtained as described in the Experimental Section. The melting temperature for the DNA alone was $80.5^{\circ} \mathrm{C}$, while the $T_{m}$ for ct-DNA in the presence of AH3 and complexes $\mathbf{1}$ and
2 were $80.0,78.0$ and $79.5^{\circ} \mathrm{C}$ respectively. A slight decrease of $\mathrm{T}_{\mathrm{m}}$ was obtained for AH3, while significant decrease was observed for complexes $\mathbf{1}$ and $\mathbf{2}$ (Table 2) indicating that the interaction of these metal complexes with ct-DNA leads to a destabilization of the double helix of DNA [42].

Viscosity measurements are considered as one of the most unambiguous methods to determine intercalation or non-intercalation binding of complexes to DNA, due to the viscosity experiments reveal changes in the length of the DNA double helix [43]. The results of the viscosity measurements for AH3 and complexes $\mathbf{1}$ and $\mathbf{2}$ are shown in Fig. 5. AH3 showed slightly decreased in relative viscosity of the DNA, while complexes $\mathbf{1}$ and $\mathbf{2}$ decreased markedly the CT-DNA solution viscosity indicating that these compounds do not intercalate the bases of the DNA molecule [44]. Similar behaviour to that observed for complexes $\mathbf{1}$ and $\mathbf{2}$ have been reported for compounds that form bond with DNA helix, such as cisplatin [45]. 

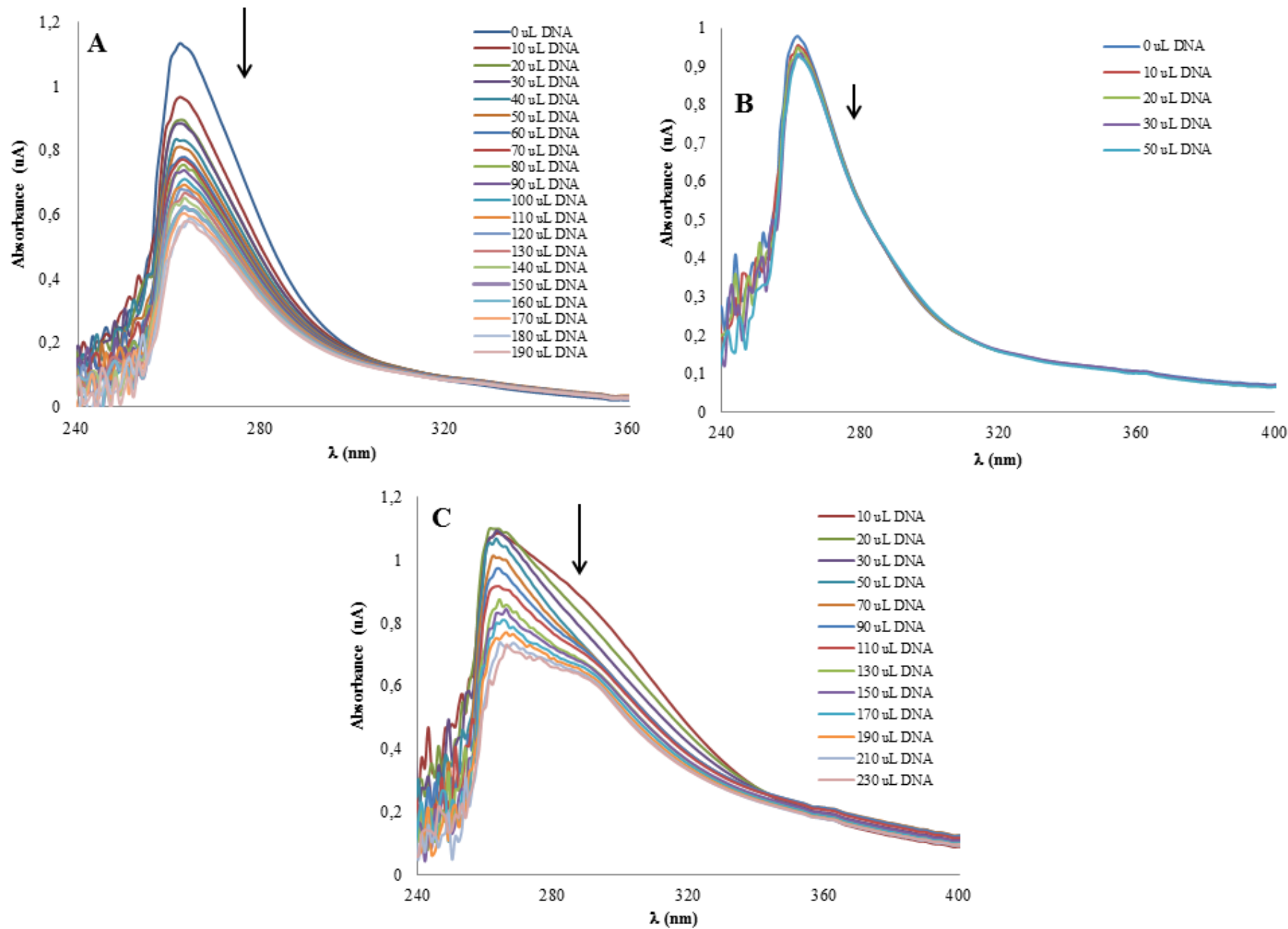

Fig. 3. Spectrometric titration spectra of $\mathbf{A H 3}(\mathrm{A})$, complex $\mathbf{1}$ (B) and complex $\mathbf{2}(\mathrm{C})$. [compound] $=\mathbf{5 x 1 0}{ }^{-4} \mathbf{M}$ and $[\mathrm{DNA}]$ 0-150 $\mu \mathrm{M}$.

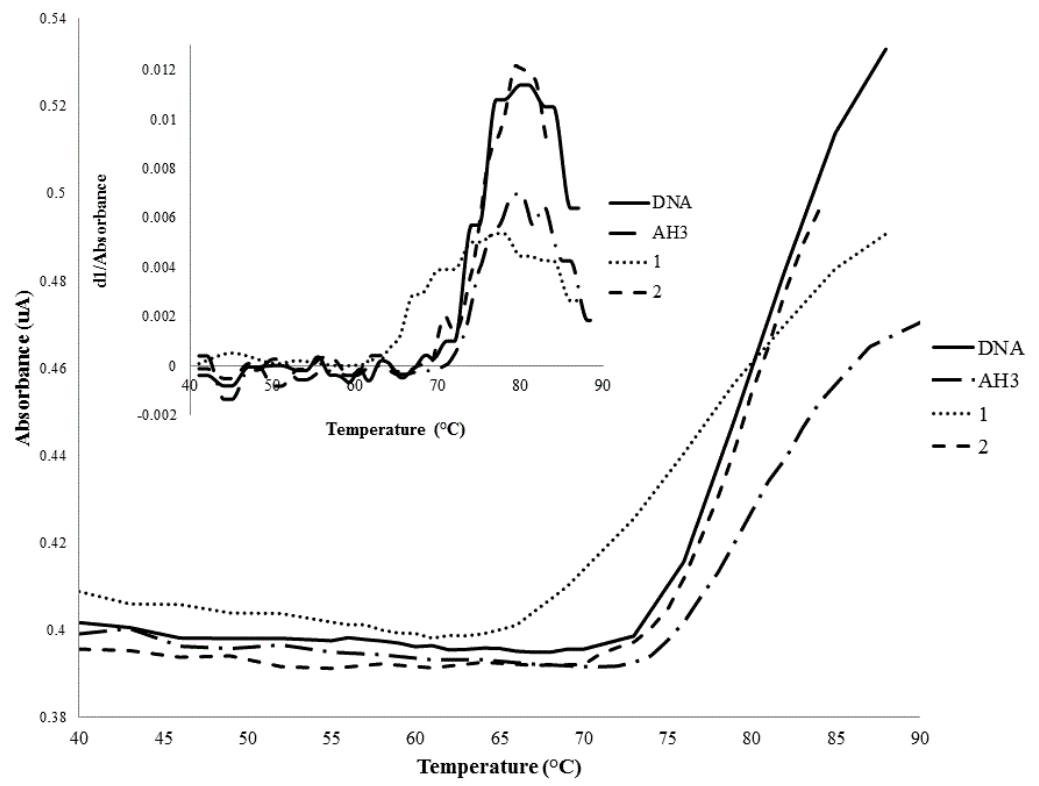

Fig. 4. Melting curves of DNA alone and in the present of the $\mathbf{A H 3}$ and complexes $\mathbf{1}$ and $\mathbf{2}$ ( $\mathrm{Ri}=0.1$ (relation [Compound]/[DNA]), incubated for $1 \mathrm{~h}$ at $25^{\circ} \mathrm{Cin} 50 \mathrm{mM} \mathrm{NaClO}_{4}$ and $5 \mathrm{mMTris} / \mathrm{HCl}$ buffer $(\mathrm{pH}=7.29)$. 
Table 2. Data obtained for the binding constants $\left(\mathbf{K}_{\mathbf{b}}\right)$, hypochromism, Red shift and melting temperature $\left(\mathrm{T}_{\mathrm{m}}\right)$ for interaction of $\mathbf{A H 3}$ and complexes 1-2 with DNA.

\begin{tabular}{|c|c|c|c|c|}
\hline complexes & $\mathrm{K}_{\mathrm{b}}\left(\mathrm{mol} \mathrm{L}^{-1}\right)^{-1}$ & (\%) hypochromism & Red shift nm $(\lambda)^{*}$ & $\Delta \mathrm{T}_{\mathrm{m}}\left({ }^{\circ} \mathrm{C}\right)$ \\
\hline $\mathrm{AH} 3$ & $2.0 \times 10^{3}$ & 50 & $4(264)$ & -0.5 \\
\hline 1 & $0.3 \times 10^{3}$ & 5 & $0(262)$ & -2.5 \\
\hline
\end{tabular}

* The peak corresponding to the red shift is shown in brackets. $\mathrm{T}_{\mathrm{m}}$ for DNA alone was $80.5^{\circ} \mathrm{C}$.

Based on the changes of absorbance, thermal denaturation and viscosity obtained complexes $\mathbf{1}$ and $\mathbf{2}$, together with the good similarity observed when comparing their data with those well known for cisplatin interacting with the DNA, we suggest that these metal complexes could bind covalently to DNA. It is possible to envisage a metal complexes-like mechanism involving solvation of the chloride in the case of complex $\mathbf{1}$ and nitrate for complex $\mathbf{2}$, and most likely to result in a covalent bonding between the metal and a DNA base. Studies to confirm the covalent binding will be performed in the future.

\section{Thioreducin reductase (TrxR) interaction studies}

Thioredoxins are the major cellular protein disulfide reductases and are responsible for the regulation of numerous biochemical processes within the cell [46], since it is an essential enzyme for the efficient maintenance of the cellular redox homeostasis. Therefore, it should be considered as an attractive target for metallodrugs [26,47]. Various gold complexes showed strong affinity for TrxR allowing deactivation due to the formation of a covalent bond to the selenium center of the enzyme [27].

The inhibitory potential of $\mathbf{A H 3}$ and their gold (1) and copper (2) complexes were studied using the dithiobisnitrobenzoic acid (DTNB) reduction assay using isolated rat liver TrxR. This assay makes use of the fact that TrxR reduces the disulfide bonds

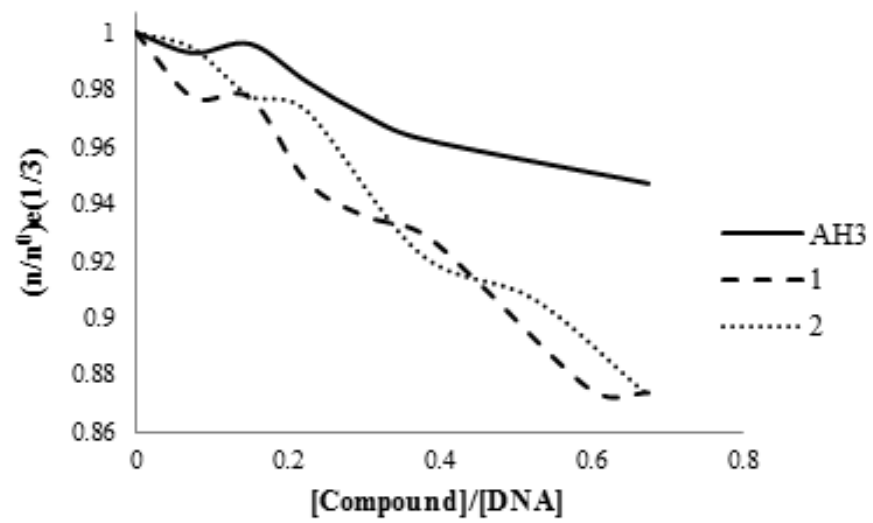

Fig. 5. Effect of increasing concentration of the complexes on the relative viscosity of DNA at $25^{\circ} \mathrm{C}$. of DTNB with formation of 2-nitro-5-thionitrobenzoic acid (TNB), which can be detected photometrically. The $\mathrm{IC}_{50}$ values for $\mathbf{A H 3}, \mathbf{1}$ and $\mathbf{2}$ were calculated using the data from the plots of the formation of TNB versus time for each compound (Fig. $6 \mathrm{~A}$ and $6 \mathrm{C}$ ), which are related to the percentage of the TrxR activity of each compound relative to the control (Fig. 6B and 6D). Complex 1 inhibited the enzyme activity at nanomolar concentrations $\left(\mathrm{IC}_{50}=22.2 \mathrm{nM}\right)$, while $\mathbf{A H 3}$ and $\mathbf{2}$ did not inhibit TrxR, even at the highest concentrations $(>500 \mu \mathrm{M})$. Clearly, complex 1 was the best inhibitor of this kind of compound, indicating that inhibition of TrxR is selective for gold complexes as it has been reported by other researchers [26-29], since this could bind to the selenium atom in the active site of the enzyme, thereby inhibiting its ability to oxide-reduction [48].

\section{Lipophilicity determination}

The partition coefficient $(\log P)$ is defined as the ratio of the equilibrium concentrations of a substance dissolved in a biphasic system which consists of two largely immiscible (water or buffer and n-octanol). It is the most widely used method for measuring the chemical compound's lipophilicity [49]. This value is determinative of the potential pharmacological use of drugs, since it has a great influence on the absorption properties, distribution, metabolism, and excretion of the drug in the body. Additionally, it is well known that the hydrophobic effect is the greatest driving force for binding of drugs to their targets [50]. As shown in Table 3, the values of $\log P$ obtained for AH3 and $\mathbf{1}$ were 0.11 and 0.35 , indicating that these compounds have preference for the organic phase (octanol), revealing its lipophilic behaviour [51]. Because of this feature, such compounds may penetrate the cell membrane, which is mainly formed by lipids, and then perform their respective biological action. With respect to complex $2, \log P$ value was -0.39 , implying that this compound has preference for the aqueous phase, with hydrophilic behaviour [52]. This fact can be attributed to the ionic characteristic of the complex $\mathbf{2}$, and suggests that this copper complex as a potential drug could be delivered directly into the bloodstream [53].

Since there is an important need to design and develop drugs that intercept cellular pathways that involve identified drug targets for relevant diseases such as pathogenic infection, genetic disorders, among others, we decided to establish 

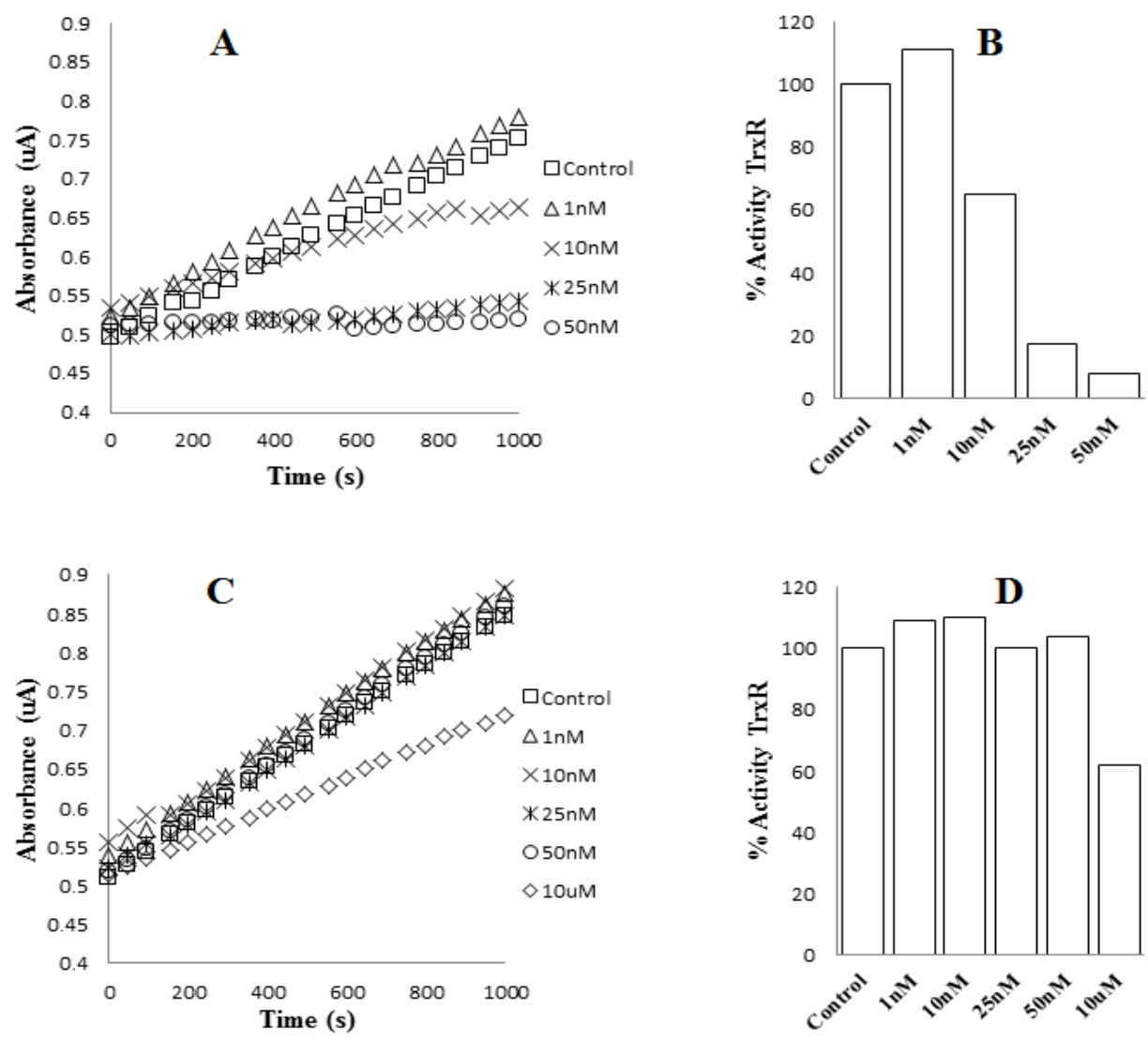

Fig. 6. Inhibition of the thioredoxin reductase activity by compounds $\mathbf{1}$ and $\mathbf{2}$.

Table 3. Experimental $\log P$ values of compounds AH3, 1 and 2.

\begin{tabular}{cc}
\hline Compound & $\log P$ \\
\hline AH3 & 0.11 \\
1 & 0.35 \\
2 & -0.39 \\
\hline
\end{tabular}

whether the new metal-AH3 derivatives interact with DNA, an important biological target for different illnesses, as well as study the inhibition of another important target like TrxR, particularly for gold complex. Below we present the first screening of their pharmacological potential against the fungus Sporothrix spp.

\section{Biological Activities}

\section{Antiproliferative activity to fungal cells}

Antifungal activity of azasterol (AH3) and its metal complexes $[\mathrm{Au}(\mathbf{A H 3}) \mathrm{Cl}](\mathbf{1})$ and $\left[\mathrm{Cu}(\mathbf{A H 3})_{2}\left(\mathrm{H}_{2} \mathrm{O}\right)_{2}\right]\left(\mathrm{NO}_{3}\right)_{2}(\mathbf{2})$ were evaluated against yeasts of the reference isolates $S$. schenckii CBS 132984 and S. brasiliensis CBS 133021. Minimum inhibitory concentration (MIC) values - the lowest concentration of the compound that inhibits fungal growth - were determined (Table 4).

All compounds were highly effective against the tested yeast, with MIC in the high nanomolar or low micromolar range. The biological activity of the AH3 is found to be the same than that of the itraconazol standard antifungal. Indeed, both compounds showed a $\mathrm{MIC}=2.5 \mu \mathrm{M}$ against the CBS 132984 strain, and a $\mathrm{MIC}=1.25 \mu \mathrm{M}$ against the CBS 133021 strain.

$\mathrm{Cu}$ (II) complex (2) showed similar fungal activity against both yeast strains with a MIC of $2.5 \mu \mathrm{M}$. Moreover, comparing its activity with $\mathbf{A H 3}$, it is possible to see that the copper atom did not modify the activity of the azasterol. In contrast, $\mathrm{Au}(\mathrm{I})$ complex (1) showed marked activity, exhibiting MIC values of 0.3 and $0.16 \mu \mathrm{M}$ against $S$. schenckii and $S$. brasiliensis respectively.

It is important to highlight that AH3 was synthesized as analogue of azasterol H3 (Sterol hydrazone class), because it has shown a significant anti-proliferative activity against $S$. schenckii and $S$. brasiliensis, even better than itraconazole [13]. Thus, it can be seen from Table 4 that, this new azasterol called AH3, also inhibited fungal growth at low micromolar concentration. In addition, we can say that the antifungal potency displayed by $\mathrm{AuCl}(\mathbf{A H 3})$ (1) is approximately 8-fold higher than AH3 and itraconazole, thus indicating that our strategy for the 
Table 4. Susceptibility of Sporothrix schenckii and Sporothrix brasiliensis yeasts to compounds AH3, $\mathbf{1}$ and $\mathbf{2}$, compared to itraconazole.

\begin{tabular}{lcc}
\hline & & \multicolumn{2}{c}{ Minimum inhibitory concentration $(\mu \mathrm{M})$} \\
\cline { 2 - 3 } & Compounds & S. schenckii \\
\hline $\mathrm{AH} 3$ & 2.5 & 1.25 \\
{$[\mathrm{Au}(\mathbf{A H 3}) \mathrm{Cl}](\mathbf{1})$} & 0.3 & 0.16 \\
{$\left[\mathrm{Cu}(\mathbf{A H 3})_{2}\left(\mathrm{H}_{2} \mathrm{O}\right)_{2}\right]\left(\mathrm{NO}_{3}\right)_{2}(\mathbf{2})$} & 2.5 & 2.5 \\
Itraconazole & 2.5 & 1.25 \\
\hline
\end{tabular}

development of new alternative chemotherapies against fungal infection based on the coordination of ergosterol biosynthesis inhibitors to metal-containing fragments, with the aim of enhancing their activity, was correct.

In Brazil, sporotrichosis is a serious public health problem, principally in Southeast Brazil, mainly due to feline transmission [54]. S. schenckii and S. brasiliensis are the most pathogenic Sporothrix species, and more frequently isolates in Brazil [55]. In the cases of $S$. brasiliensis, treatment with itraconazole is often not effective [56]. Thus, $[\mathrm{Au}(\mathbf{A H 3}) \mathrm{Cl}](\mathbf{1})$ is a compound with potential for development of new antifungal agent for sporotrichosis treatments. However, additional studies are needed to evaluate in vivo efficacy and safety of this molecule.

\section{Conclusion}

Three new compounds were synthesized and characterized through elemental analysis, UV-Vis, IR and NMR as described here. The new azasterol (AH3) was coordinated to different metals such as $\mathrm{Au}$ and $\mathrm{Cu}$. These metal-AH3 derivatives most probably interact with the DNA via covalent binding. Only complex 1 inhibits TrxR. AH3 and complex $\mathbf{1}$ are lipophilic compounds, while complex $\mathbf{2}$ showed a hydrophilic behaviour. The activities of these metal complexes were investigated against fungus causing sporotrichosis. Our results showed that all compounds were highly effective against the tested yeast. Gold-AH3 complex was the most promising agent for the development of new anti-sporotrichosis compound.

\section{Experimental Section}

\section{General Procedure}

All manipulations were routinely carried out under $\mathrm{N}_{2}$ using common Schlenck techniques. Solvents were purified using standard procedures immediately prior to use. Melting points were measured on a Buchi apparatus and are uncorrected. $\mathrm{C}, \mathrm{H}$ and $\mathrm{N}$ analyses were performed with a Carlo Erba EA1108 elemental analyzer. The NMR spectra were obtained in $\mathrm{CDCl}_{3}$ and in a DMSO-d 6 solution in a Bruker AVANCE 300 spectrometer. ${ }^{1} \mathrm{H}$ NMR shifts were recorded relative to residual proton resonances in the deuterated solvent. IR spectra were obtained with a Nicolet Magna IR 560 spectrometer. UV-vis spectra were recorded on a HP 8453 diode array instrument.

\section{Synthesis of the new sterol hydrazine and its derivatives of gold and copper}

3 $\beta$-tetrahydropyraniloxy-23,24-bisnor-5-cholenic acid (II) $3 \beta$-hydroxy-23,24-bisnor-5-cholenic acid I (1.807 g; 5.22 mmol) was suspended in tetrahydrofuran (THF, $10 \mathrm{~mL}$ ). 3,4 -[2H]-dihydropyran $(2.36 \mathrm{~mL} ; 26.04 \mathrm{mmol})$ and catalytic amount of p-toluenesulfonic acid hydrated $(210 \mathrm{mg} ; 1.10 \mathrm{mmol})$ were added. The solution was stirred at room temperature for 24 hours, becoming a dark yellow solution. To this solution were added $20 \mathrm{~mL}$ of $\mathrm{NaHCO}_{3}$ and $10 \mathrm{~mL}$ of $\mathrm{CH}_{2} \mathrm{Cl}_{2}$. The aqueous phase was extracted 3 times with portions of $20 \mathrm{~mL}$ of dichloromethane. The resulting organic phase was acidified with $5 \mathrm{~mL}$ of $\mathrm{CH}_{3} \mathrm{COOH}$ and washed 3 times with $50 \mathrm{~mL}$ of water, then dried with $\mathrm{Na}_{2} \mathrm{SO}_{4}$ and concentrated. (2.156 g, 96\%). ${ }^{1} \mathrm{H} \mathrm{NMR}$ $\left(\mathrm{CDCl}_{3}, 500 \mathrm{MHz}\right) \delta 5.32$ (1H, t, H-6), 4.71 (1H, t, H-1'), 3.90 $\left(1 \mathrm{H}, \mathrm{m}, \mathrm{H}-5\right.$ '), 3.48 (2H, m, H3 and $\left.\mathrm{H}-5^{\prime}\right), 1.22$ (3H, d, $J=6.81$ Hz, H-21), 0.99 (3H, s, H-19), 0.68 (3H, s, H-18).

\section{3 $\beta$-tetrahydropiraniloxy-23-bisnorchol-5-en-22-ol (III)}

To a solution of $3 \beta$-tetrahydropyranyloxy-23,24-bisnor-5-cholenic acid (II) $(1.0 \mathrm{~g} ; 2.32 \mathrm{mmol})$ in dry tetrahydrofuran at $0{ }^{\circ} \mathrm{C}$ was added $\mathrm{LiAlH}_{4}(91.1 \mathrm{mg} ; 2,40 \mathrm{mmol})$. This solution was placed under stirring and then allowed to heat at $25^{\circ} \mathrm{C}$ for 12 hours. The reaction was stopped with water in an ice bath. The reaction was extracted with 3 portions of $15 \mathrm{~mL}$ of chloroform and then the organic phase was washed with 3 portions of water. Dried with $\mathrm{Na}_{2} \mathrm{SO}_{4}$, then filtered, concentrated and purified through silica gel column with a mixture of solvent hexane: ethyl acetate 4:1. (861 mg, 89\%). ${ }^{1} \mathrm{H} \mathrm{NMR}\left(\mathrm{CDCl}_{3}, 500 \mathrm{MHz}\right)$

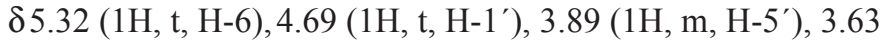
(1H, m, H-22), 3.49 (2H, m, H-3 and $\left.\mathrm{H}-5^{\prime}\right), 3.34$ (1H, m, H-22), $1.03(3 \mathrm{H}, \mathrm{d}, J=6.57 \mathrm{~Hz}, \mathrm{H}-21), 0.99$ (3H, s, H-19), 0.68 (3H, s, H-18).

3ß-tetrahydropyranyloxy-23-bisnorchol-5-en-22-bromine (IV) N,N,N',N'-tetramethyl ethylenediamine $(270 \mu \mathrm{L} ; 1.80 \mathrm{mmol})$, carbono tetrabromide $(655 \mathrm{mg} ; 1.98 \mathrm{mmol})$ and triphenylphosphine (572 mg; $2.18 \mathrm{mmol}$ ) were added to a solution of $3 \beta$-tetrahydroxipyraniloxy-23-bisnorchol-5-en-22-ol (III) (680 $\mathrm{mg} ; 1.63 \mathrm{mmol})$ in dry dichloromethane. The solution was left 
under constant stirring at room temperature for one hour, noticing a yellow solution. This solution was concentrated, dissolved in ethyl acetate and passed through a silica gel column using as mobile phase hexane: ethyl acetate 6:1. (751 mg. 96\%). ${ }^{1} \mathrm{H}$ NMR $\left(\mathrm{CDCl}_{3}, 500 \mathrm{MHz}\right) \delta 5.32(1 \mathrm{H}, \mathrm{t}, \mathrm{H}-6), 4.68\left(1 \mathrm{H}, \mathrm{t}, \mathrm{H}-1^{\prime}\right)$, $3.89\left(1 \mathrm{H}, \mathrm{m}, \mathrm{H}-5^{\prime}\right), 3.49$ (3H, m, H3, H-5' and H-22), $3.34(1 \mathrm{H}$, m, H-22), 1.07 (3H, d, $J=6.45$ Hz, H-21), 0.98 (3H, s, H-19), 0.68 (3H, s, H-18).

\section{2-bromine-23-bisnorchol-5-en-3 $\beta$-ol (V)}

To a solution of $3 \beta$-tetrahydropyranyloxy-23-bisnorchol-5-en22-bromine IV (749 $\mathrm{mg} ; 1.56 \mathrm{mmol})$ in ethanol $(25 \mathrm{~mL})$ was added concentrated hydrochloric acid ( $1 \mathrm{~mL} ; 10.15 \mathrm{mmol})$ and placed under reflux for 30 minutes. Acid was neutralized with $1 \mathrm{~N}$ sodium hydroxide, and extracted with 3 portions of chloroform. Then organic phase was concentrated and a white solid was precipitated. (605 mg. 98\%). ${ }^{1} \mathrm{H} \mathrm{NMR}\left(\mathrm{CDCl}_{3}, 500 \mathrm{MHz}\right)$ $\delta 5.32(1 \mathrm{H}, \mathrm{t}, \mathrm{H}-6), 3.48$ (2H, m, H-3 and H-22), $3.32(1 \mathrm{H}, \mathrm{m}$, H-22), 1.07 (3H, d, $J=6.48$ Hz, H-21), 0.98 (3H, s, H-19), 0.68 (3H, s, H-18).

\section{2-hydrazine-imidazolin-2-yl-chol-5-en-3 $\beta$-ol (AH3)}

A solution of 2-hydrazine-2-imidazoline hydrobromide (197 $\mathrm{mg} ; 1.09 \mathrm{mmol})$ and 1,8-diazabicyclo [5.4.0] undec-7-ene (DBU) $(161 \mu \mathrm{L} ; 1.08 \mathrm{mmol})$ in acetonitrile $(15 \mathrm{~mL})$ was placed under stirring for five minutes, then 22-bromine-23-bisnorchol5-en-3 $\beta$-ol (V) (150 mg; $0.38 \mathrm{mmol}$ ) was added, and placed under reflux for 24 hours. After this time the solution was concentrated, dissolved in butanol and washed with saturated sodium chloride. The organic phase was concentrated and washed with a solution of hexane: ethyl acetate $4: 1$, then diethyl ether, and finally dried under vacuum. A light orange solid was obtained. (113 mg, 72\%). Amorphous power: $\mathrm{mp} 230-232^{\circ} \mathrm{C}$; IR $(\mathrm{KBr}) \mathrm{v}_{\max } 3417,2933,2866,1640 \mathrm{~cm}^{-1} .{ }^{1} \mathrm{H}$ NMR (DMSO-d ${ }_{6}$, $500 \mathrm{MHz}) \delta 5.25$ (1H, t, H-6), $5.04(1 \mathrm{H}, \mathrm{s}, \mathrm{NH}), 3,56(4 \mathrm{H}, \mathrm{s}$, $\mathrm{H}-24$ and $\mathrm{H}-25), 1.01(3 \mathrm{H}, \mathrm{d}, J=6.70 \mathrm{~Hz}, \mathrm{H}-21), 0.93(3 \mathrm{H}, \mathrm{s}$, H-19), 0.65 (3H, s, H-18). ${ }^{13} \mathrm{C}$ RMN (DMSO-d 6 ) $\delta 163.73$ (C23), 141.25 (C-5), 120.36 (C-6), 69.98 (C-3), 56.04 (C-22), 42.36 - 42.21 (C2-4, C-25), 19.01 (C-21), 16.98 (C-19), 12.11 $(\mathrm{C}-18) . \varepsilon_{(264 \mathrm{~nm}, \mathrm{DMSO})}=2840 \mathrm{M}^{-1} \mathrm{~cm}^{-1}$. ESI-MS (MeOH) $\mathrm{m} / \mathrm{z}$ : $415 \mathrm{M}^{+}$. Anal. C $63.34 \%$, N $11.94 \%$, H $10.35 \%$, calcd for $\mathrm{C}_{25} \mathrm{H}-$ ${ }_{42} \mathrm{~N}_{4} \mathrm{O} \cdot 3.5 \mathrm{H}_{2} \mathrm{O}, \mathrm{C} 62.86 \%$, N $11.73 \%$, H $10.34 \%$.

\section{Chloro(22-hydrazine-imidazolin-2-yl-chol-5-en-3 $\beta$-ol)gold(I)}

(1)

To a solution of (chloro(tetrahydrothiophene)gold (108.0 mg; 0,34 mmol) in dry dichloromethane was added AH3 (145,0 mg; $0,38 \mathrm{mmol})$. The solution was left under constant stirring at room temperature for 96 hours. A violet solid after filtration was obtained. Then it was washed with three solvents as follow, first dichloromethane, second acetonitrile, third diethyl ether, and finally dried under vacuum. (175 mg. 49\%). Amorphous power: mp 278-280 ${ }^{\circ} \mathrm{C}$; IR (KBr) $\mathrm{n}_{\max } 3441,2934,1634 \mathrm{~cm}^{-1}$. ${ }^{1} \mathrm{H}-\mathrm{NMR}\left(\mathrm{DMSO}_{\mathrm{d}}, 500 \mathrm{MHz}\right) \delta 5.25(1 \mathrm{H}, \mathrm{t}, \mathrm{H}-6), 5.09(1 \mathrm{H}, \mathrm{s}$, $\mathrm{NH}), 3.33$ (4H, s, H-23 and H-24), $0.82(3 \mathrm{H}, \mathrm{d}, J=6.95 \mathrm{~Hz}$,
H-21), 0.93 (3H, s, H-19), 0.69 (3H, s, H-18). ${ }^{13} \mathrm{C}-\mathrm{NMR}$ (DMSO-d 6 ) d161.48 (C-23), 141.27 (C-5), 120.32 (C-6), 69.98 (C3), 55.88 (C-22), 42.38 - 42.19 (C-24, C-25), 19.12 (C-21), 17.07 (C-19), 12.07 (C-18). $\varepsilon_{(262 \mathrm{~nm}, \mathrm{DMSO})}=3691 \mathrm{M}^{-1} \mathrm{~cm}^{-1}$. Anal. C 47.08\%, N 10.50\%, H 6.80\%, calcd. for $\mathrm{C}_{25} \mathrm{H}_{42} \mathrm{AuCl}-$ $\mathrm{N}_{4} \mathrm{O} \cdot \mathrm{CH}_{3} \mathrm{CN}$ : C $47.13 \%$, N 10.18\%, H 6.59\%.

[Dinitrate-di(22-hydrazine-imidazoline-2-yl-chol-5-en-3 $\beta$-ol) copper (II)] (2)

To a blue solution of copper(II) nitrate trihydrate (92.2 mg; 0.37 mmol) in methanol, was added AH3 (103.6 mg; $0.25 \mathrm{mmol}$ ), the solution became light green. Then, the solution was placed under reflux at constant stirring for 2 hours. The solvent was filtrated and the green solid was washed with acetonitrile and diethyl ether. (139 mg. 55\%). Amorphous power: mp 200-202 ${ }^{\circ} \mathrm{C}$. IR (KBr) $\mathrm{n}_{\max } 3353,2926,1657,1384,1049 \mathrm{~cm}^{-1} .{ }^{1} \mathrm{H}-\mathrm{NMR}$ $\left(\mathrm{DMSO}_{6}, 500 \mathrm{MHz}\right) \delta 5.24(1 \mathrm{H}, \mathrm{t}, \mathrm{H}-6), 4.57(1 \mathrm{H}, \mathrm{s}, \mathrm{NH})$, 3.63 (4H, s, H-23 and H-24), 0.89 (3H, s, H-21), 0.92 (3H, s, H-19), 0.66 (3H, s, H-18). $\varepsilon_{(262 \mathrm{~nm}, \text { DMSO })}=4236 \mathrm{M}^{-1} \mathrm{~cm}^{-1}$. Anal. C $46.90 \%$, N $13.13 \%$, H 7.56\%, calcd. for $\mathrm{C}_{25} \mathrm{H}_{46} \mathrm{CuN}_{6} \mathrm{O}_{9}$ : C $47.05 \%$, N $13.17 \%$, H $7.26 \%$.

\section{Lipophylicity determination}

The logarithm of the partition coefficient between $n$-octanol and water $(\log P)$ is a universally accepted physicochemical model of these important biological effects, and is a very widely used parameter in medicinal chemistry [57]. The partition coefficient of the complex between n-octanol $(o)$ and water $(w)$ was studied by the shake-flask method. Drugs were dissolved at a concentration of $1 \mathrm{mM}$ in the aqueous phase $(3 \mathrm{~mL})$. An equal volume of saturated $n$-octanol was added and the solutions were mixed in the water-bath for $30 \mathrm{~min}$. The organic and aqueous phases were separated and the concentration of drug in each phase was measured by UV-visible. The logarithm of the ratio of compound concentration in the organic and aqueous phases was calculated to determine $\log P$ values [58].

\section{DNA interactions}

All the measurements with calf thymus (ct) DNA were carried out in buffer Tris- $\mathrm{HCl} 5 \mathrm{mM}$ (pH 7.2), $50 \mathrm{mM} \mathrm{NaCl}$. The UV absorbance ratio $\lambda_{260} / \lambda_{280}$ was $1.8-1.9$ indicating that the DNA was essentially free of protein [59]. The ct-DNA concentration per nucleotide was determined by absorption spectrophotometric analysis using the molar absorption coefficient 6600 $\mathrm{mol}^{-1} \mathrm{dm}^{3} \mathrm{~cm}^{-1}$ at $260 \mathrm{~nm}$ [60].

The spectroscopic titrations were carried out by adding increasing amounts of ctDNA to a solution of the compound at a fixed concentration in a quartz cell, and recording the UV-Vis spectra after each addition. The absorption by DNA was subtracted by adding the same amounts of ct-DNA to the blank. The intrinsic binding constant $\mathrm{K}_{\mathrm{b}}$ was determined from the plot of [DNA] $/\left(e_{a}-e_{f}\right)$ vs [DNA], where [DNA] is the concentration of DNA in base pairs, and the apparent absorption 
coefficients, $\varepsilon_{\mathrm{a}}, \varepsilon_{\mathrm{f}}, \varepsilon_{\mathrm{b}}$ correspond to $\mathrm{A}_{\mathrm{obs}} /[$ compound], the extinction coefficient for the free compound and the extinction coefficient of the compounds in the totally bound form, respectively. The data were fitted to Eq. 1 , with a slope equal to $1 /\left(\varepsilon_{\mathrm{b}}\right.$ - $\left.\varepsilon_{\mathrm{f}}\right)$ and the intercept equal to $1 /\left[\mathrm{Kb}\left(\varepsilon_{\mathrm{b}}-\varepsilon_{\mathrm{f}}\right)\right]$ and $\mathrm{Kb}$ was obtained from the ratio of the slope to the intercept [61].

$[D N A] /\left(\varepsilon_{\mathrm{a}}-\varepsilon_{\mathrm{f}}\right)=[\mathrm{DNA}] /\left(\varepsilon_{\mathrm{b}}-\varepsilon_{\mathrm{f}}\right)+1 /\left[\mathrm{K}_{\mathrm{b}}\left(\varepsilon_{\mathrm{b}}-\varepsilon_{\mathrm{f}}\right)\right]$

The interaction of these compounds (AH3, $\mathbf{1}$ and $\mathbf{2}$ ) with ct-DNA was also measured in thermal denaturation experiments. Melting curves were recorded in media containing 50 $\mathrm{mM} \mathrm{NaClO}_{4}$ and $5 \mathrm{mMTris} / \mathrm{HCl}$ buffer $(\mathrm{pH}=7.29)$. The absorbance of the ct-DNA solution $(\sim 60 \mu \mathrm{M})$ with $\mathrm{Ri}=0.1$ (relation [Compound]/[DNA]) was monitored at $260 \mathrm{~nm}$ before and after incubation with the drug $(\sim 7 \mu \mathrm{M}$ in Tris/ $\mathrm{HCl}$ buffer $)$ for $1 \mathrm{~h}$ at room temperature. The temperature was increased by $1{ }^{\circ} \mathrm{C} / \mathrm{min}$ between 65 and $85{ }^{\circ} \mathrm{C}$ and by $3^{\circ} \mathrm{C} / \mathrm{min}$ between 40 and $65^{\circ} \mathrm{C}$ and between 85 and $94^{\circ} \mathrm{C}$ [62].

Viscosity measurements were carried out using an Ostwald viscometer immersed in a water bath maintained at $25^{\circ} \mathrm{C}$. The DNA concentration was kept constant in all samples, while the compound concentration was increased from 0 to $67 \mu \mathrm{M}$. The flow time was measured at least 6 times with a digital stopwatch and the mean value was calculated. Data are presented as $\left(\eta / \eta^{0}\right)^{1 / 3}$ versus the ratio [compound]/[DNA], where $\eta$ and $\eta^{0}$ are the specific viscosity of DNA in the presence and absence of the compound, respectively. The values of $\eta$ and $\eta^{0}$ were calculated by use of the expression $\left(t-t^{b}\right) / t^{b}$, where $t$ is the observed flow time and $t^{b}$ is the flow time of buffer alone. The relative viscosity of the DNA was calculated from $\eta / \eta_{0}[63]$.

\section{TrxR interaction}

TrxR inhibition experiments were carried out using a TrxR rat liver kit and bovine serum albumin (BSA), both obtained from Sigma -Aldrich. The kit containing the EDTA phosphate buffer needed to carry out the experiment. Kinetic control was performed on a plate reader "TECAN Sunrise absorbance reader", using 96-well plates with flat bottom. A working buffer phosphate $\mathrm{pH} 7.0$, with $20 \mathrm{mM}$ EDTA, $20 \mu \mathrm{g} / \mathrm{mL}$ BSA and $0.5 \mu \mathrm{g} /$ $\mathrm{mL}$ of enzyme TrxR rat liver was prepared. This buffer was distributed into the wells of the plate, and then incubated for 10 minutes at room temperature with different concentrations of compound dissolved in DMSO. In the case of the control sample, was added the same volume of DMSO to the working buffer. After this time, the reaction was initiated with the addition of 5,5'-dithiobis (2- nitrobenzoic acid) (DTNB, included in the kit), which when is reduced by the enzyme system provides a direct measurement of the TrxR activity [64]. The kinetics was studied for about 16 minutes, making measurements every 16 seconds. The $\mathrm{IC}_{50}$ were calculated as the concentration of compound decreasing the enzymatic activity of the untreated control by $50 \%$.

\section{Antifungal activity tests}

Yeasts of reference isolates Sporothrix schenckii CBS 132984 and Sporothrix brasiliensis CBS 133021 were obtained from filamentous form (saprophytic form) cultivated in potato agar dextrose agar (PDA) and then cultivated in brain heart infusion broth supplemented with $2 \%$ glucose, at $36^{\circ} \mathrm{C}$, with orbital agitation (150 rpm) for 7 days. Antifungal activity of compounds were determined according to the minimum inhibitory concentrations (MIC), and compared to the gold standard drug itraconazole (Sigma Chemical Co.). MIC values were determined by broth microdilution test of the CLSI reference method M27-A3 adapted to Sporothrix spp. yeasts [13].

The compounds were kept as $20 \mathrm{mM}$ stock solutions in DMSO at $-20^{\circ} \mathrm{C}$. Immediately before use, compounds were diluted in Roswell Park Memorial Institute (RPMI) 1640 medium supplemented with $2 \%$ glucose, into 96-well microliter, at final concentration ranging from 20 to $0.04 \mu \mathrm{M}$. Then, yeasts were added into microliter and a final yeast concentration ranging from $0.5-1 \times 10^{5} \mathrm{CFU}$ (colonies form units) $/ \mathrm{mL}$ were treated for $48 \mathrm{~h}$, at $35^{\circ} \mathrm{C}$, in a $5 \% \mathrm{CO}_{2}$ chamber. Minimum concentrations that inhibited pronouncedly fungal growth relative to untreated control were determined by visual inspection in an inverted light microscope, and confirmed by spectrophotometric readings at $490 \mathrm{~nm}$, in a microliter plate reader (Molecular Devices SpectraMax Plus), corresponding to inhibitions as from $80 \%$. These percentage of inhibition was calculated according following equation: $100-(\mathrm{A} \times 100 / \mathrm{C})$, where $\mathrm{A}$ is the absorbance value of wells containing compound and $\mathrm{C}$ is absorbance of control wells. Results are representative of two independent experiments made in duplicate.

\section{Acknowledgments}

The authors are grateful to the analytical team for the elemental analysis at INMETRO and IVIC. The fungal isolates used in this study were kindly provided by Dr. Zoilo Pires de Camargo and Dr. Anderson Messias Rodrigues from the Universidade Federal de São Paulo (UNIFESP, São Paulo, SP, Brazil). This work was supported by FONACIT-Venezuela, Conselho Nacional de Desenvolvimento Científico e Tecnológico (CNPq, Brazil), Fundação Carlos Chagas Filho de Amparo à Pesquisa do Estado do Rio de Janeiro (FAPERJ, Brazil), Coordenação de Aperfeiçoamento de Pessoal de Nível Superior (CAPES).

\section{References}

1. Pagán-Mercado, G.; Rivera-Ruiz, M. E.; Segarra-Román, F.; Rodríguez-Medina, J. R. P. R. Health Sci. J. 2009, 28, 220-226.

2. Urbina, J.; Vivas, J.; Visbal, G.; Contreras, L. M. Mol. Biochem. Parasitol. 1995, 73, 199-210.

3. Urbina, J. A.; Vivas, J.; Lazardi, K.; Molina, J.; Payares, G.; Piras, M. M.; Piras, R. Chemotherapy. 1996, 42, 294-307. 
4. Haughan, P. A.; Change, M. L.; Goad, L. J. Biochem. J. 1995, 308, 31-38.

5. Rodrigues, J. C. F.; Bernardes, C. F.; Visbal, G.; Urbina, J. A.; Vercesi, A. E.; de Souza, W. Protist. 2007, 158, 447-456.

6. Visbal, G.; Marchan. E.; Maldonado, A.; Simoni, Z.; Navarro, M. J. Inorg. Biochem. 2008, 102, 547-554.

7. Urbina, J. A.; Visbal, G.; Contreras, L. M.; McLaughlin, G.; DoCampo, R. Antimicrob. Agents. Chemother.1997, 41, 1428-1432.

8. Visbal, G.; Alvarez, A.; Moreno, B.; San-Blas, G. Antimicrob. Agents. Chemother.200 3, 47, 2966-2970.

9. Visbal, G.; San-Blas, G.; Maldonado, A.; Álvarez-Aular, A.; Capparelli, M. V.; Murgich, J. Steroids. 2011,76, 1069-1081.

10. Ishida, K.; Rodrigues, J. C. F.; Ribeiro, M. D.; Vila, T. V.; de Souza, W.; Urbina, J. A.; Nakamura, C. V.; Rozental, S.B. M. C. Microbiol. 2009, 9, 74.

11. Vivas, J.; Alvarado, P.; Visbal, G.; Alvarez-Aular, A.; Ruiz, E.; Ledezma, E. Invest. Clin. 2011, 52, 312-322.

12. Visbal, G.; San-Blas, G.; Murgich, J.; Franco, H. Curr. Drug Targets: Infect Disorders. 2005, 5, 211-226.

13. Borba-Santos, L.; Visbal, G.; Gagini, T.; Rodrigues, A M.; de Camargo, Z.; Lopes-Bezerra, L.; Ishida, K; de Souza, W.; Rozental, S. Front. Microbiol. (Online). 2016, 7:311, 1-13.

14. Sánchez-Delgado R.; Navarro M.; LazardiK.; UrbinaJ.; Atencio, R.; Noels, A. N. Inorg. Chim. Acta. 1998, 275, 528-540.

15. Sanchez-Delgado, R. A.; Anzellotti, A. Mini rev. Med. Chem. 2004, 4, 23-30.

16. Navarro, M.; Cisneros-Fajardo, E. J.; Lehmann, T.; Sánchez-Delgado, R.; Atencio, R.; Silva, P.; Lira, R.; Urbina, J. Inorg.Chem. 2001, 40, 6879-6884.

17. Navarro, M.; Lehmann, T.; Cisneros-Fajardo, E. J.; Fuentes, A.; Sánchez-Delgado, R.; Silva, P.; Urbina, J. Polyhedrom. 2000, 19, 2319-2325.

18. Iniguez, E.; Sánchez, A.; Vasquez, M. A.; Martínez, A.; Olivas, J.; Sattler, A.; Sánchez-Delgado, R. A.; Maldonado, R. A. J. Biol. Inorg. Chem. 2013,18, 779-790.

19. Martínez, A.; Carreon, T.; Iniguez, E.; Anzellotti, A.; Sánchez, A.; Tyan, M.; Sattler, A.; Herrera, L.; Maldonado, R. A.; SánchezDelgado, R. A. J. Med. Chem. 2012, 55, 3867-3877.

20. Visbal, G.; Marchan, E.; Maldonado, A.; Simoni, Z.; Navarro, M. J. Inorg. Biochem.2008, 102, 547-554

21. Navarro, M.; Marchán, E.; Maldonado, A.; Simoni, Z.; Velásquez, M.; Herrera, L.; Visbal, G. Trans. Met. Chem. 2015, 40, 707-713.

22. Long, E. C.; Barton, J. K. Acc. Chem. Res. 1990, 23, 271-273.

23. Pages, B. J.; Ang, D. L.; Wright, E. P.; Aldrich-Wright, J. R. Dalton Trans. 2015, 44, 3505-3526.

24. García-Ramos J. C.; Galindo-Murillo, R.; Cortés-Guzmán, F.; Ruiz-Azuara, L. J. Mex. Chem. Soc. 2013, 57, 245-259.

25. Navarro, M.; Castro, W.; González, S.; Abad, M. J.; Taylor, P. J. Mex. Chem. Soc. 2013, 57, 220-229.

26. Berners-Price, S. J.; Filipovska, A. Metallomics, 2011, 3, 863-873.

27. Nobili, S.; Mini, E.; Landini, I.; Gabbiani, C.; Casini, A.; Messori, L. Med. Res. Rev., 2010, 30, 550-580.

28. Lessa, J. A.; Guerra, J. C.; de Miranda, L. F.; Romeiro, C. F. D.; Da Silva, J. G.; Mendes, I. C.; Speziali, N. L.; Souza-Fagundes, E. M.; Beraldo, H. J. Inorg. Biochem. 2011, 105, 1729-1739.

29. Liu, W.; Bensdorf, K.; Proetto, M.; Abram, U.; Hagenbach, A.; Gust, R. J. Med. Chem. 2011, 54, 8605-8615.

30. Chakrabarti, A.; Bonifaz, A.; Gutierrez-Galhardo, M. C.; Mochizuki, T.; Li, S.Med. Mycol. 2015, 53, 3-14.

31. Medici, N. P.; Del Poeta, M. Mem Inst Oswaldo Cruz, Rio de Janeiro. 2015, 110, 966-973.
32. Kauffman, C. A.; Bustamante, B.; Chapman, S. W.; Pappas, P. G. Clin. Infect. Dis. 2007, 45, 1255-1265.

33. Rodrigues, A. M., de Hoog, G. S., de Cássia Pires, D.; Brilhante, R.S.; Gadelha, M. F.; Colombo, A. L.; de Camargo, Z. P. BMC. Infect. Dis. 2014, 14, 219.

34. Borba-Santos, L. P.; Rodrigues, A. M.; Gagini, T. B.; Fernandes, G. F.; Castro, R.; de Camargo, Z. P.; Nucci, M.; Lopes-Bezerra, L. M.; Ishida, K.; Rozental, S. Med. Mycol. 2015, 53, 178-188.

35. K. Nakamoto, Coordination Compounds. In Infrared and Raman Spectra of Inorganic and Coordination Compounds, 4th Ed.; John Wiley and Sons, Inc.: New York, (1986).

36. Wilkinson, G. Comprehensive Coordination Chemistry. Eds. Pergamon, 1987.

37. Pages, B. J.; Ang, D. L.; Wright, E. P.; Aldrich-Wright, J. R. Dalton Trans. 2015, 44, 3505-3526.

38. García-Ramos, J. C.; Galindo-Murillo, R.; Cortés-Guzmán, F.; Ruiz-Azuara, L. J. Mex. Chem. Soc. 2013, 57(3), 245-259.

39. Topală, T.; Bodoki, A.; L Oprean, L.; Radu O. Farmacia, 2014, Vol. 62, 6, 1049-1061.

40. Barton, J. K.; Danishefsky, A.; Goldberg, J. J. Am. Chem. Soc. 1987, 106, 2172.

41. Navarro M.; Corona, O.; Colmenares, I.; Marchan, E.; Lett. Drug Des. Discov. 2006, 3:7, 454-458.

42. Ussery, D. W. DNA Denaturation. Academic Press, New York, 2001.

43. Satyanarayana, S.; Dabrowiak, J. C.; Chaires, J. B. Biochemistry. 1992, 31, 9319-9324.

44. Navarro, M.; Betancourt, A.; Hernández, C.; Marchán, E. J. Braz. Chem. Soc. 2008, 19, 1355.

45. Cohen, G.; Eisemberg, H. Biopolymers. 1969, 8, 45-55.

46. Holmgren, A. Annu. Rev. Biochem. 1985, 54, 237-271.

47. Barry, N. P. E.; Sadler, P. J. Chem. Commun. 2013, 49, 5106-5131.

48. Liu, W.; Bensdorf, K.; Proetto, M.; Abram, U.; Hagenbach, A.; Gust, R. J. Med. Chem. 2011, 54, 8605-8615.

49. McKeage, M.; Berners-Price, S.; Galettis, P.; Bowen, R.; Brouwer, W.; Ding, L.; Zhuang, L.; Baguley, B. Cancer Chemother. Pharmacol. 2000, 46, 343-350.

50. Sarkarand, A.; Kellogg, G. E. Curr. Top. Med. Chem. 2010, 10(1): 67-83.

51. Leo, A.; Hansch, C.; Elkins, D. Chem. Rev. 1971, 71, 525-616.

52. Martínez, A.; Rajapakse, C. S. K.; Naoulou, B.; Kopkalli, Y.; Davenport, L.; Sánchez-Delgado, R. A. J. Biol. Inorg. Chem. 2008, 13, 703-712.

53. Martínez, A.; Rajapakse, C. S. K.; Jalloh, D.; Dautriche, C.; Sánchez-Delgado, R. A. J. Biol. Inorg. Chem. 2009, 14, 863-871.

54. Rodrigues, A. M.; de Melo Teixeira, M.; de Hoog, G.S.; Schubach, T. M. P.; Pereira, S. A.; Fernandes, G. F.; Lopes Bezerra, L. M.; Sueli Felipe, M.; de Camargo, Z. P. PLoS Negl. Trop. Dis. 2013, 7(6): e2281.

55. Zhang, Y.; Hagen, F.; Stielow, B.; Rodrigues, A. M.; Samerpitak, K.; Zhou, X.; Feng, P.; Yang, L.; Chen, M.; Deng, S.; Li, S.; Liao, W.; Li, R.; Li, F.; Meis, J. F.; Guarro, J.; Teixeira, M.; Al-Zahrani, H. S.; de Camargo, Z. P.; Zhang, L.; de Hoog, G. S. Persoonia. 2015, 35, 1-20.

56. Reis, É. G.; Schubach, T. M.; Pereira, S. A.; Silva, J. N.; Carvalho, B. W.; Quintana, M. S.; Gremião, I. D. Med Mycol. 2016, 54, 684-690.

57. Tetko, I. V.; Jaroszewicz, I.; Platts, J. A.; Kuduk-Jaworska, J. J. Inorg.Biochem. 2008, 102, 1424-1437.

58. Hansch, C.; Bjorkroth, J. P.; Leo, A. J. Pharm. Sci. 1987, 76, 663-687. 
59. Hay, P. J.; Wadt, W. R. J. Chem. Phys. 1985, 82, 299.

60. Marmur, J. J. Mol. Biol. 1961, 3, 208-218.

61. Reichmann, M. E.; Rice, S. A.; Thomas, C. A.; Doty.; P. J. Am. Chem. Soc. 1954, 76, 3047-3053.

62. Martínez, A.; Rajapakse, C. S. K.; Naoulou, B.; Kopkalli, Y.; Davenport, L.; Sánchez-Delgado, R. A. J. Biol. Inorg. Chem. 2008, 13, 703-712.
63. Navarro, M.; Hernandez, C.; Colmenares, I.; Hernandez, P.; Fernandez, E.; Sierraalta, A.; Marchan, E. J. Inorg. Biochem. 2007, 101, 111-116.

64. Fang, J.; Lu, J.; Holmgren, A. J. Biol. Chem. 2005, 280, 2528425290. 